\title{
Selective Hematological, Biochemical and Pathological Alterations of Newcastle Virus in Naturally Infected and Vaccinated Broilers in Damietta Governorate of Egypt
}

\author{
Shefaa A. M. El-Mandrawy and Shimaa A. A. Ismail * \\ Department of Clinical pathology, Faculty of Veterinary Medicine, Zagazig University 1 Alzeraa Street, \\ Postal Code 44511, Zagazig City, Sharkia Province, Egypt. \\ * corresponding author: shifo_vet@yahoo.com.
}

Bulletin UASVM Veterinary Medicine 74(2)/2017

Print ISSN 1843-5270; Electronic ISSN 1843-5378

doi:10.15835/buasvmcn-vm:0002

\begin{abstract}
Newcastle disease (ND) remains one of the most harmful poultry diseases that threaten the poultry industry producers all over the world, thus the present work was planned to investigate the hematological, biochemical, and pathological changes in vaccinated and non-vaccinated broiler chickens naturally infected with ND. The study was conducted on 45 broiler chickens, 35-days-old, from a private farm in Damietta governorate and used in this work, 15 chickens were clinically healthy (Group I), 30 chickens with ND symptoms divided into 15 non-vaccinated (Group II) and the other 15 chickens (Group III) were vaccinated with La Sota strain of NDV with a titre of 106.5 EID50. The disease was diagnosed by hem agglutination test as ND. Blood and tissue samples were collected for clinical-pathological and histopathological examination. The infected broiler chickens showed cyanosis, nasal discharge, edema of eyelid and white pasty diarrhea with nervous manifestations. Furthermore, microcytic hypochromic anemia with leukocytosis was observed. Biochemical studies revealed a significant decrease in serum total proteins, albumin and A/G ratio, with significant increases in serum activities of aspartate aminotransferase, creatinine, and uric acid and glucose concentration in addition to several histological alterations were significantly seen in brain, intestine, liver and kidney of the infected birds. All these disturbances were less severe in the vaccinated group than the non-vaccinated one. In conclusion, La Sota vaccine can increase the bird resistant against Newcastle disease virus induced blood disorders and hepatic-renal insufficiency in broiler chickens.
\end{abstract}

Keywords: Newcastle disease virus, Broilers, La Sota, Hematobiochemical, Histopathology.

\section{INTRODUCTION}

Blood analyses have been performed much less often in avian medicine in comparison to its routine use in large animal practices in veterinary medicine. Serum biochemical parameters may provide valuable information about the health status of birds (Kral and Suchy, 2000). Biochemical values of chicken's serum may be influenced by several factors including poultry diseases (Koinarski et al., 2001; Burnham et al., 2003; Kumar et al., 2003). Poultry diseases including Newcastle disease, infectious bronchitis and infectious bursal disease affect serum values of some biochemical parameters in chickens (Talebi, 2006).
Newcastle disease (ND) remains the most harmful diseases in the poultry industry that threaten the poultry producers all over the world, in spite of the presence of ND vaccinations since the 1950s (Alexander, 2003). Strains of Newcastle disease virus (NDV) belong to Mononegavirales, family Paramyxoviridae, and genus Avulavirus, are contained in one serotype and are also known as avian paramyxovirus serotype-1 (APMV-1). There are 5 pathologic types of ND in chickens: viscerotropic velogenic $\mathrm{ND}$, neurotropic velogenic $\mathrm{ND}$, mesogenic, lentogenic and asymptomatic-enteric form (Darrell et al., 2013). 
NDV was isolated from livers and kidneys of the experimentally challenged broilers (Njagi et al., 2012). It had been found to induce high mortalities in infected broilers with extensive hepatic, splenic, lymphoid and pancreatic tissues damage as well as severe conjunctival hemorrhage and no purulent encephalitis (Nakamura et al., 2008). The purpose of the present work was to investigate the hematological, biochemical, and histopathological changes in La Sota vaccinated or non-vaccinated broilers naturally infected with NDV.

\section{MATERIAL AND METHODS}

Newcastle Disease Virus Vaccine: La Sota strain of NDV with a titer of 106.5 EID50 was supplied from Abbassia Laboratories in Egypt.

Ethical approval: Handling and sampling were carried out using the general guidelines of the National Institutes of Health (NIH) for the Care and Use of Laboratory Animals in scientific investigations and approved by the ethics of animal use in research committee (EAURC), Zagazig University.

Animal grouping: 45 broiler chickens, 35-days-old were obtained from private farm in Damietta governorate and selected as following; 15 birds were clinically healthy, showed -vet hem agglutination test and kept as control group (I), 15 non-vaccinated birds with signs of ND infection and +ve hem agglutination test were kept as NDinfected non-vaccinated group (II) and 15 La Sota 106.5 EID50 -vaccinated birds with signs of ND infection and + ve hem agglutination test were kept as ND-infected -vaccinated group (III).

Sampling: Clinical signs were recorded then two blood samples were collected at the same time from wing vein from all tested groups. The first set of blood samples $(0.5 \mathrm{ml}$ from each broiler chickens) were collected in dipotassium salt of ethylene- diamintetraacetic acid (EDTA) tubes to be used for hematological variables determination. While the second blood samples $(5 \mathrm{ml}$ from each broiler chickens) were taken without anticoagulant in a sterile test tube for serum separation and kept for biochemical analysis. Postmortem findings were recorded then brain, small intestine, liver and kidney specimens were taken from freshly dead birds for histopathological examination.

Hematological studies: Erythrocyte and leukocyte counts were performed using an improved Neubauer hem cytometer and Natt and Herrick solution as a special diluent for chicken's blood according to Samour (2006). The packed cell volume was estimated by micro hematocrit centrifuge according to Coles (1986). Hemoglobin estimation was performed using the cyanomethemoglobin colorimetric method after centrifugation according to Zijlstra (1960). Mean corpuscular volume (MCV), mean corpuscular hemoglobin concentration (MCHC) were calculated. Blood films were made, fixed by absolute methyl alcohol, and then stained by Giemsa stain for differential leukocyte count and detection of RBCs morphology abnormalities according to Feldman et al. (2000).

Clinical-biochemical analysis: All biochemical tests were measured calorimetrically using a commercial kits of BioMed-Diagnostic ,EGYCHEM for lab technology, Badr City, Industrial Area Piece 170, 250 Fadan In East of Elrubaki, Egypt on a semi-automated Photometer (5010 V5+, RIELE $\mathrm{GmbH} \& \mathrm{Co}$, Berlin, Germany). Serum aspartate aminotransferase (AST) and alanine aminotransferase (ALT) were measured according to the method of Reitman and Frankel (1957), serum total proteins and creatinine levels were determined according to Henry (1974), serum albumin level was estimated by the method of Doumas et al. (1981). Serum globulins level was calculated by subtracting the obtained albumin level from the obtained total proteins level (Doumas and Biggs, 1972). Glucose was determined by the method of Trinder (1969). Serum uric acid was measured by the method previously obtained by Sanders and Pasman (1980).

\section{Histopathological examination}

Tissue specimens from the brain, small intestine, liver and kidney were collected from all animals within each group, and were immediately fixed with $10 \%$ buffered formaldehyde. Thereafter, routine paraffin wax blocks were prepared for each specimen, and were used for obtaining $5 \mu \mathrm{m}$ thick tissue sections. These sections were later stained with hematoxylin and eosin (H\&E) for analysis using light microscopy (Thijs et al., 1999).

A histopathological scoring system was used to assess the severity of the lesions in the examined organs. For each organ, five tissue sections were examined, and scores were assigned to significant lesions (see Tables 4 and 5) according to the following scale: 0 ; nil, 1 ; mild, 2 ; moderate, 3 ; severe. For group comparisons, scores for individual birds from each group were used for the calculation of the average plus or minus the SD. The scores per individual birds 
were obtained by examining five different tissue sections per organ bird Student t-test was used to compare lesions scores between the diseased and the vaccinated group $(\mathrm{P}<0.05)$.

Statistical analysis: Data of the current study was statistically analyzed using the computer program SPSS/PC+2001. The statistical method was one way ANOVA test, followed by Duncan's multiple range test (Duncan, 1995). Data are presented as means plus or minus the standard error. The minimum level of significance was set at $\mathrm{P}<0.05$.

\section{RESULTS AND DISCUSSION}

ND is an economically essential listed and highly frequent isolated worldwide virus due to its importance to the commercial poultry producers and trading countries. Controlling of NDV through vaccination is commonly and routinely applied by the majority of poultry production companies to supply an immunological response against the disease (Darrell et al., 2013).

\section{Clinical observations:}

As shown in fig.(1), ND-infected non-vaccinated birds of group (II) showing high mortalities with cyanosis, nasal discharge, edema of eyelid, white pasty diarrhea and nervous manifestations. These clinical signs of ND have been previously described (Cheville et al. 1972; Lancaster, 1981; McFerran and McCracken, 1988; Parede and Young, 1990; Kouwenhoven, 1993; Alexander, 1997). Furthermore, nervous signs were seen in the infected poultry and confirmed with the histological alteration detected in the brain which represented by presence of cerebral encephalitis, characterized by marked aggregations of lymphocytes and plasma cells within the connective tissue matrix. In addition, perivascular lymphocytic cuffing was observed in the cerebral cortex, which is characteristic for viral infections (Helmy et al., 2007).

\section{Hematological results:}

Concerning the hemogram as shown in tables (1 and 2), ND-infected non-vaccinated broilers of group (II) showed a significant $(\mathrm{P}<0.05)$ decrease in the values of RBCs, $\mathrm{Hb}$, PCV, MCHC with significant increase in MCV showing features of macrocytic hypochromic anemia. The hematological response in the chickens revealed significant depression of RBCs, $\mathrm{Hb}, \mathrm{PCV}$ and MCHC with significant increase of MCV in the ND-infected non-vaccinated chickens (gp.II) when compared with the controls indicating macrocytic hypochromic anemia (Velguth et al., 2010). The severe anemia observed in the infected non-vaccinated chickens may likely be due to possible intravascular hemolysis and blood loss usually seen in form of proventricular hemorrhages and GI ulcers in VND (Calderon et al., 2005). The elevated mean corpuscular volume in chickens indicated that circulating RBCs was immature red cells (reticulocytosis) with less hemoglobin better described as macrocytic hypo-chromic anemia. Progressive degeneration and necrosis of precursor cells in hematopoietic islands of the bone marrow
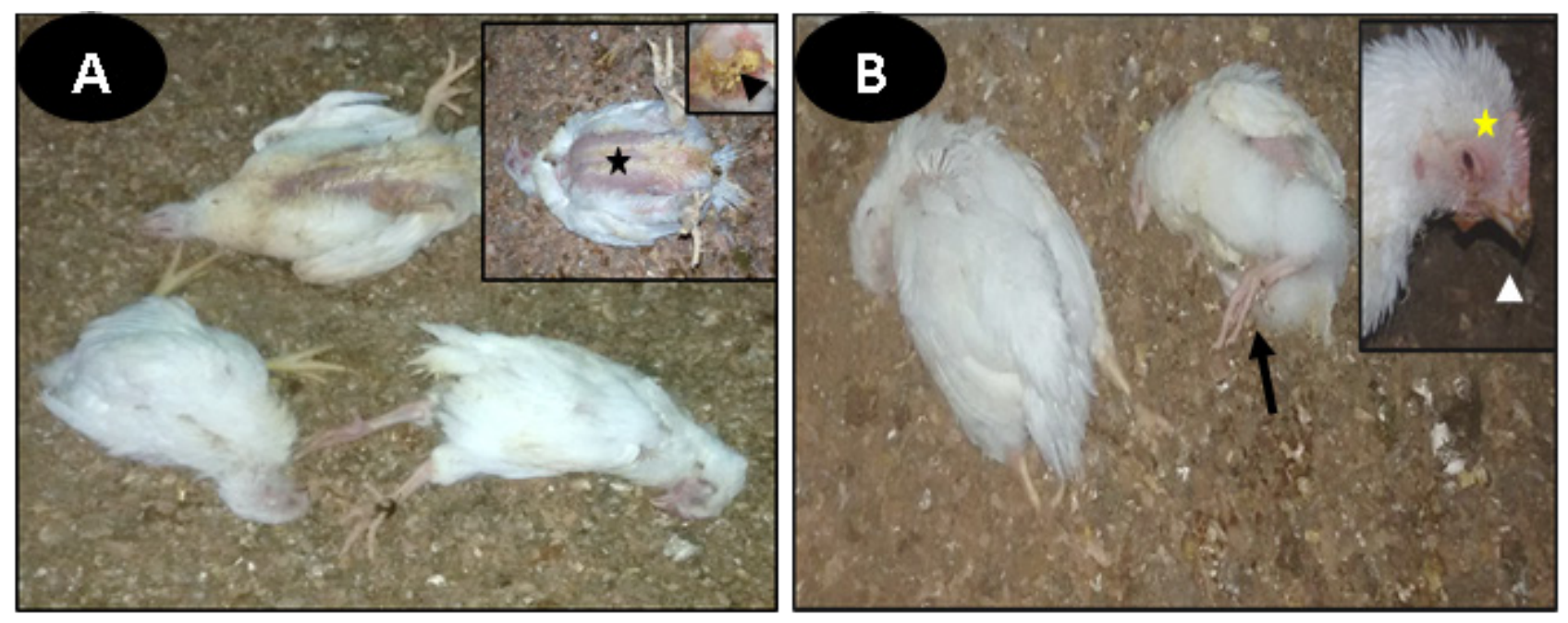

Fig.1: Representative photo showing dead non-vaccinated birds naturally infected with ND; (A) showing signs of cyanosis (black star), white pasty diarrhea (black arrowhead), (B)showing nervous manifestation (arrow), nasal discharging (white arrowhead), and edema of eye lids(yellow star). 
observed by Calderon et al. (2005) are supported by the hematological findings of our study and have been previously reported by Goryo et al. (1989) and Ojok and Brown (1996).

Leukocytopenia, heteropenia, lymphocytopenia and eosinopenia compared to the negative control group (I).Meanwhile, the infectedvaccinated group (III) showed significant marked improvement in the fore-mentioned parameters compared to the infected non-vaccinated group but not reach the level of normal control. Leukocytopenia was observed in the ND-infected non-vaccinated chickens (gp.II) compared to the control group (I) in the present study with heteropenia, lymphocytopenia which may be attributed to the marked depression and elevation reactions of the white blood cells of chickens during ND (Coles, 1986). The leukocytic alterations recorded in this study indicate that NDV exert marked depression on leucogram in chickens, as reported by Calderon et al. (2005). Lymphocytopenia recorded in chicken may be associated with depletion of lymphocytes in the bursa of Fabricus, spleen and thymus as reported by Ezema et al. (2009). The observed lymphocytopenia of acute infection may have complex mechanisms which include endogenous corticosterone release with temporary lymphocyte redistribution, and trapping of circulating lymphocytes within lymphoid tissue, especially, during viral infection (Schmidt et al., 2008). A sequential study in chickens after NDV was made by Harrison et al. (2011) who detected that the virus induced programmed cell death principally in mononuclear cells-macrophages and lymphocytes. Lymphocytopenia is common in acute inflammatory responses, because inflammatory mediators stimulate the diapedetic migration of heterophils and lymphocytes from the blood and lymphoid tissues to the points of inflammation where they are eventually destroyed (Ng et al., 2005). This may account for the immunosuppression previously reported in NDV in chickens (Ezema et al., 2009). Hemogram

Tab. 1. Erythrogram of birds in different groups (I-III) $(n=15$, mean \pm SE)

\begin{tabular}{lccccc}
\hline & $\begin{array}{c}\text { RBCs } \\
\left(\times 10^{6} / \mathrm{mm}^{3}\right)\end{array}$ & $\begin{array}{c}\mathrm{Hb} \\
(\mathrm{g} / \mathrm{dl})\end{array}$ & $\begin{array}{c}\text { PCV } \\
(\%)\end{array}$ & MCV (fl) & $\begin{array}{c}\text { MCHC } \\
(\%)\end{array}$ \\
\hline $\begin{array}{l}\text { Control gp (I) } \\
\begin{array}{l}\text { ND-infected non- } \\
\text { vaccinated gp (II) }\end{array}\end{array}$ & $1.58^{\mathrm{a}} \pm 0.36$ & $9.20^{\mathrm{a}} \pm 0.58$ & $41.60^{\mathrm{a}} \pm 1.96$ & $119.50^{\mathrm{b}} \pm 7.33$ & $22.08^{\mathrm{a}} \pm 1.72$ \\
$\begin{array}{l}\text { ND-infected non- } \\
\text { vaccinated gp III) }\end{array}$ & $2.77^{\mathrm{a}} \pm 0.22$ & $5.86^{\mathrm{b}} \pm 0.12$ & $31.40^{\mathrm{b}} \pm 1.02$ & $196.26^{\mathrm{a}} \pm 24.57$ & $15.48^{\mathrm{b}} \pm 0.17$ \\
\hline
\end{tabular}

All data having different letters are differ significantly at $\mathrm{p}<0.05$

Tab. 2. Leukogram $\left(\times 10^{3} / \mathrm{mm}^{3}\right)$ of birds in different groups (I-III) $(\mathrm{n}=15$, mean $\pm \mathrm{SE})$

\begin{tabular}{lcccccc}
\hline & WBCs & Hetero. & Lympho. & Eosino. & Baso. & Mono. \\
\hline Control gp (I) & $7.86^{\mathrm{a} \pm 0.32}$ & $5.03^{\mathrm{a}} \pm 0.28$ & $2.26^{\mathrm{a}} \pm 0.29$ & $0.17^{\mathrm{a}} \pm 0.03$ & $0.13^{\mathrm{a}} \pm 0.05$ & $0.25^{\mathrm{a}} \pm 0.01$ \\
$\begin{array}{l}\text { ND-infected non- } \\
\text { vaccinated gp (II) }\end{array}$ & $2.70^{\mathrm{c}} \pm 0.20$ & $1.26^{\mathrm{c}} \pm 0.09$ & $0.95^{\mathrm{b}} \pm 0.08$ & $0.08^{\mathrm{b}} \pm 0.01$ & $0.10^{\mathrm{a}} \pm 0.01$ & $0.28^{\mathrm{a}} \pm 0.03$ \\
$\begin{array}{l}\text { ND-infected non- } \\
\text { vaccinated gp III) }\end{array}$ & $3.88^{\mathrm{b}} \pm 0.26$ & $2.27^{\mathrm{b}} \pm 0.13$ & $1.09^{\mathrm{b}} \pm 0.11$ & $0.15^{\mathrm{ab}} \pm 0.02$ & $0.07^{\mathrm{a}} \pm 0.03$ & $0.29^{\mathrm{a}} \pm 0.02$ \\
\hline
\end{tabular}

All data having different letters are differing significantly at $\mathrm{p}<0.05$. Hetero; Heterophils, Lympho; Lymphocytes, Eosino; Eosinophils, Baso; Basophils, Mono; Monocytes. 
results of the present work disagree with the results recorded by Ismail (2017) who found no significant changes in erythrogram, leukocytosis, lymphocytosis and monocytosis, 42 days postinfection with NDV in broiler chickens.

\section{Biochemical changes and histopathologi- cal finding}

Regarding to the clinical-biochemical reports in comparison with the control group (I) as shown in table (3) and fig. (2) general, the histological scores obtained for each organ were significantly higher in the non-vaccinated group compared to the vaccinated group $(\mathrm{P}<0.05)$ (Figs 3,4 and Tables 4,5), ND-infected broilers of group (II) showed a significant $(\mathrm{P}<0.05)$ decrease in serum total proteins, albumin and $\mathrm{A} / \mathrm{G}$ ratio with nonsignificant changes in serum total globulins beside an increases in serum concentrations of uric acid and creatinine $(\mathrm{P}<0.05)$, this supported by histopathologial findings in the current work revealed that ND-infected non-vaccinated chickens (gp.II) showed diffuse renal tubules and the glomeruli coagulative necrosis with cystic dilatation and/or morphological distortion of some renal tubules besides damaging of the basal membrane and severe congestion of the intertubular blood vessels (El-Bahrawy, 2016). These observed structural alterations discuss our recorded biochemical results which represented by significant elevations in serum uric acid and creatinine with hypoproteinemia and hypoalbuminemia which were partially in the same line of results obtained by Ismail (2017) who found hyperproteinemia and hyperglobulinemia with elevated serum uric acid and creatinine, 42 days post-infection with NDV in broiler chickens. The infected-vaccinated group (III) showed significant marked improvement in the forementioned parameters compared to the infected non-vaccinated group and reach the level of normal control at total proteins, albumin and uric acid.

Transaminases are the most commonly used indicators of cellular necrosis and increase in serum concentration may indicate liver malfunction (Rosenthal, 1997). They occupy a central position in amino acid metabolism; the elevation observed in this study could have a consequential effect on the amino acid metabolism in the birds, it may indicate some sort of injury to the organs like liver, heart, kidney, and brain, such injury may cause leakage of enzymes from damaged organs to the blood stream, the concentration of these enzymes predict the severity of damage (Ojiezeh and Ophori, 2015). Elevated serum AST activity $(\mathrm{P}<0.05)$ in broiler chickens groups infected with NDV in the present work, indicating liver and various organs damage (McDaniel and Chute, 1961; Rivetz et al., 1975). These results were confirmed by histopathological changes seen in liver of infected non- vaccinated group, which showing congestion of hepatic veins and atrophy in the adjacent hepatocytes as previously seen by Ismail (2017).

Stress is consisted of different forms, and results in hormone releasing. It is well established that insulin is the key peptide hormone regulating the metabolism of carbohydrate and lipid in broilers. Insulin induces glucose disposal in adipose tissue and muscle, and also prevents the production of glucose in liver. In the present study, increase glucose concentration $(\mathrm{P}<0.05)$ (hyperglycemia) recorded in the ND-infected non-vaccinated birds may be a result of insulin resistance as an indicator of stress (Dupont et al., 2009) which resulted from elevated corticosterone concentration in NDV injected birds (Wang et al., 2015).

To control the spread of NDV, chickens are routinely vaccinated with NDV vaccines derived from known strains such as La Sota (Jeon et al., 2008). In this paper, La Sota-vaccinated post-ND challenge birds showed marked improvement in the hemogram, liver and kidney functions compared to the infected non-vaccinated group.

\section{CONCLUSION}

In conclusion, La Sota-vaccinated improve the antibody response and will give good protection against challenge with virulent virus.

Acknowledgement: Authors were greatly thankful to Dr/ Haiytham Ali, Lecturer of Pathology, Faculty of Veterinary Medicine, Zagazig University for his aid in reading the histopathological alterations.

Conflict of interest: No conflict of interest between authors 
Tab.3. Kidney function tests of birds in different groups (I-III) $(n=15$, mean \pm SE)

\begin{tabular}{lcccccc}
\hline & $\begin{array}{c}\text { T. proteins } \\
(\mathrm{g} / \mathrm{dl})\end{array}$ & $\begin{array}{c}\text { Albumin } \\
(\mathrm{g} / \mathrm{dl})\end{array}$ & $\begin{array}{c}\text { Globulins } \\
(\mathrm{g} / \mathrm{dl})\end{array}$ & $\begin{array}{c}\text { A/G ratio } \\
(\%)\end{array}$ & $\begin{array}{c}\text { Uric acid } \\
(\mathrm{mg} / \mathrm{dl})\end{array}$ & $\begin{array}{c}\text { Creatinine } \\
(\mathrm{mg} / \mathrm{dl})\end{array}$ \\
\hline Control gp (I) & $6.99^{\mathrm{a}} \pm 0.46$ & $4.89^{\mathrm{a}} \pm 0.09$ & $2.09^{\mathrm{a}} \pm 0.37$ & $2.58^{\mathrm{a}} \pm 0.36$ & $52.40^{\mathrm{b}} \pm 1.72$ & $1.04^{\mathrm{c}} \pm 0.12$ \\
$\begin{array}{l}\text { ND-infected non- } \\
\text { vaccinated gp (II) }\end{array}$ & $5.54^{\mathrm{b}} \pm 0.25$ & $3.39^{\mathrm{b}} \pm 0.11$ & $2.15^{\mathrm{a}} \pm 0.17$ & $1.60^{\mathrm{b} \pm 0.12}$ & $119.40^{\mathrm{a}} \pm 14.26$ & $2.29^{\mathrm{a} \pm 0.19}$ \\
$\begin{array}{l}\text { ND-infected non- } \\
\text { vaccinated gp III) }\end{array}$ & $7.05^{\mathrm{a}} \pm 0.58$ & $4.44^{\mathrm{a}} \pm 0.25$ & $2.61^{\mathrm{a}} \pm 0.34$ & $1.76^{\mathrm{a}} \pm 0.16$ & $79.00^{\mathrm{b}} \pm 12.72$ & $1.57^{\mathrm{b}} \pm 0.12$ \\
\hline
\end{tabular}

All data having different letters are differ significantly at $\mathrm{p}<0.05$

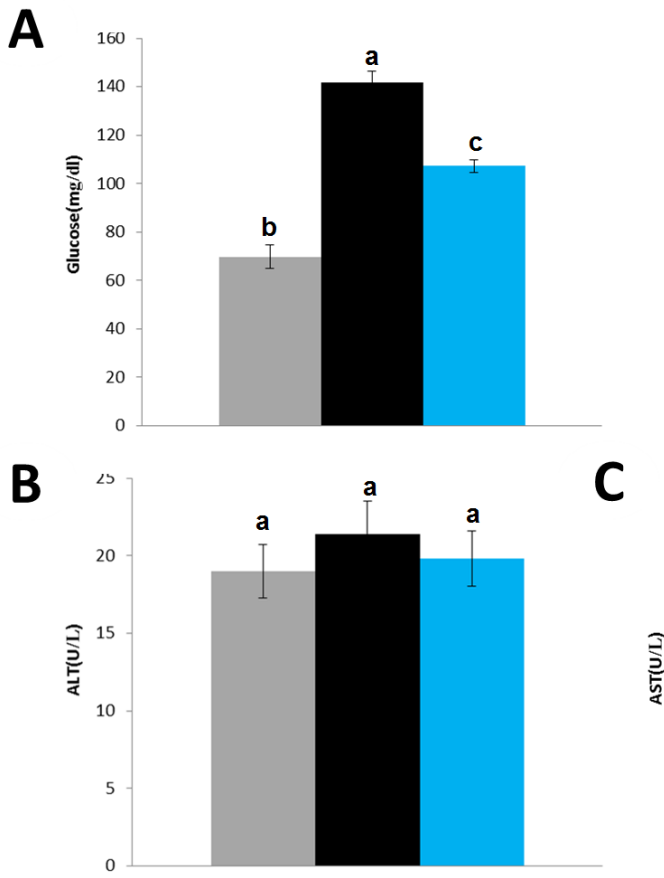

-ve control

ND-infected non-vaccinated

ND-linfected vaccinated

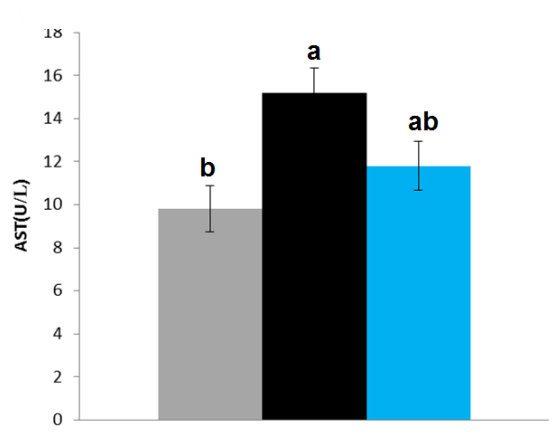

Fig. 2. Serum glucose level and AST\&ALT activities of birds in all tested groups.

Tab. 4. The main lesions considered in the histopathological scoring of the examined organs.

\begin{tabular}{lc}
\hline Organ & Lesion \\
\hline Brain & Perivascular lymphocytic cuffing \\
Small intestine & Necrosis of the mucosa and submucosa \\
& Villious desquamation \\
Kidney & Tubular necrosis \\
Liver & Congestion of intertubular blood vessels \\
\hline
\end{tabular}


Tab. 5. Comparison of lesion scores (mean \pm SD) b etween the vaccinated and non-vaccinated groups.

\begin{tabular}{lcc}
\hline Organ/lesion & Non-vaccinated & Vaccinated \\
\hline Brain & $2.7 \pm 0.5$ & $0.1 \pm 0.3^{\dagger}$ \\
Perivascular lymphocytic cuffing & & \\
Small intestine & $2.9 \pm 0.3$ & $0.2 \pm 0.4^{\dagger}$ \\
Necrosis of the mucosa and submucosa & $2.9 \pm 0.3$ & $0.4 \pm 0.5^{\dagger}$ \\
Villious desquamation & & \\
Kidney & & $0.1 \pm 0.3^{\dagger}$ \\
Tubular necrosis & $2.9 \pm 0.3$ & $0.2 \pm 0.4^{\dagger}$ \\
$\begin{array}{l}\text { Congestion of intertubular } \\
\text { blood vessels } \\
\text { Liver }\end{array}$ & $2.8 \pm 0.4$ & \\
Venous congestion & & $0.1 \pm 0.3^{\dagger}$ \\
\hline
\end{tabular}

† Indicates significant differences compared to the non-vaccinated groups at $\mathrm{P}<0.05$.

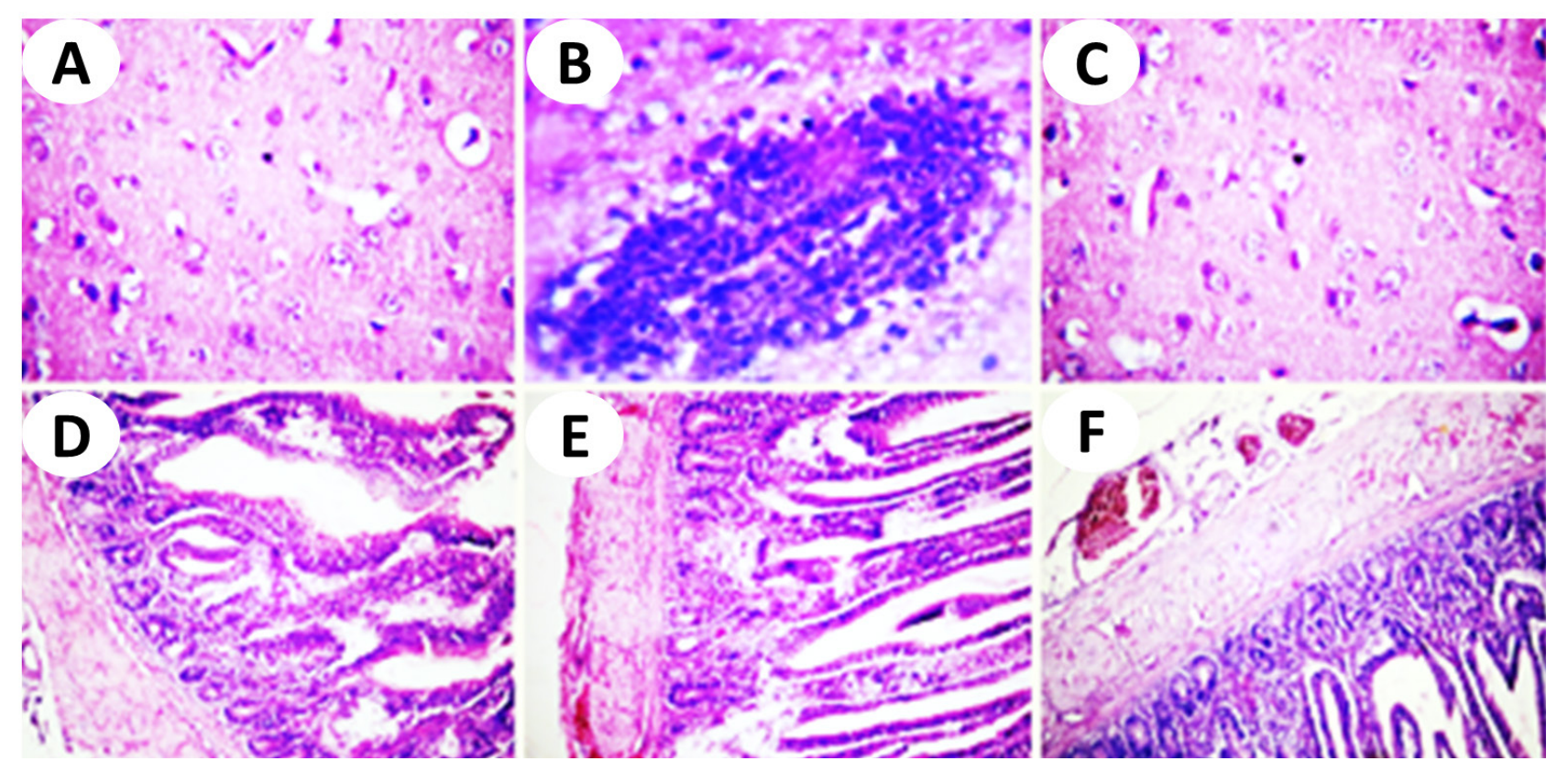

Fig. 3. Photomicrographs of H\&E-stained brain section of ND-infected non-vaccinated birds showing perivascular lymphocytic cuffing (B) (400x).The small intestine showing villous necrosis and lymphocytic infiltration in the submucosa (E) (100x). The pathological picture of the vaccinated group (C, F) was near to the non-infected control (A, D). 


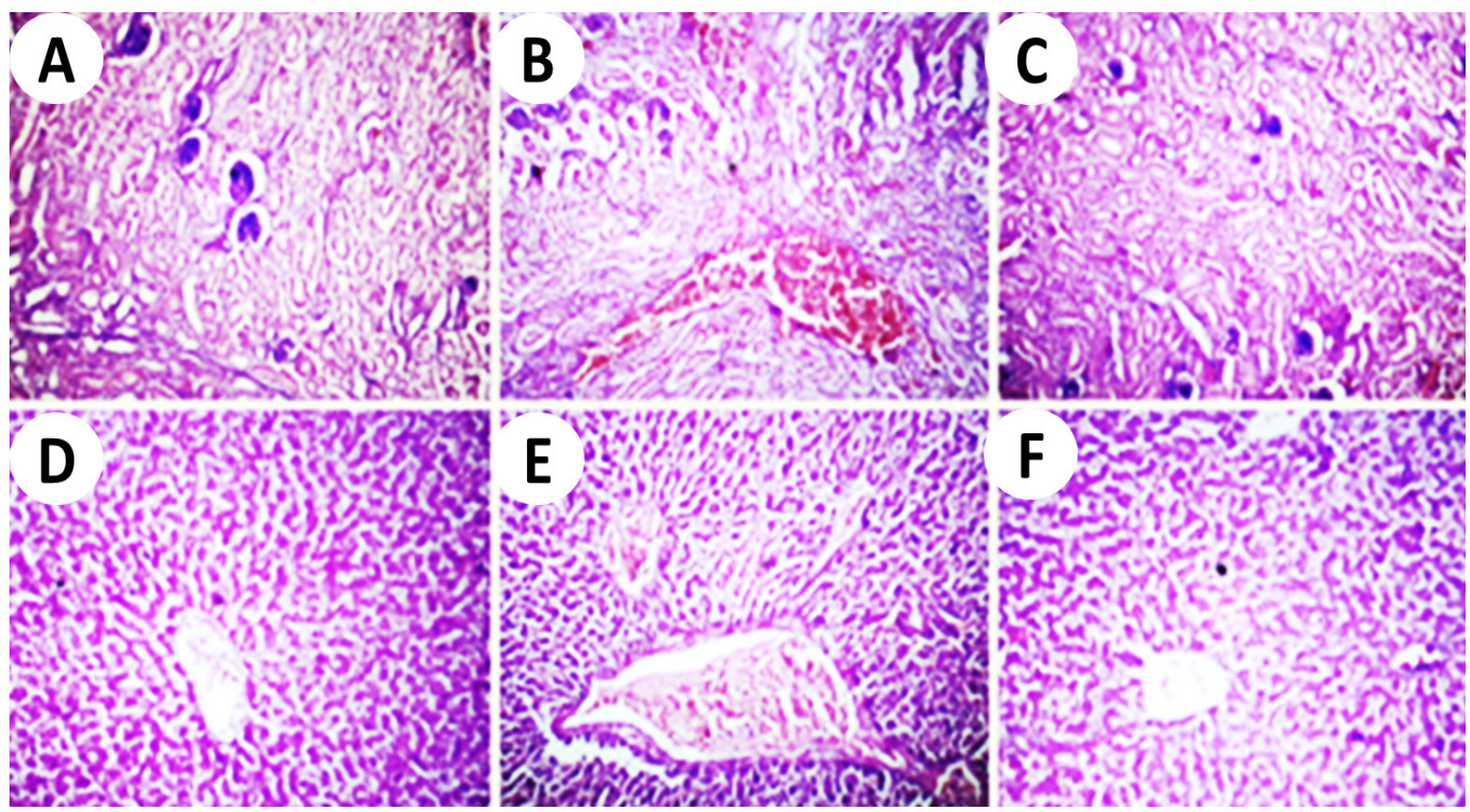

Fig. 4. Photomicrographs of H\&E-stained kidney section of ND-infected non-vaccinated birds showing tubular coagulative necrosis and congestion of intertubular blood vessels (B). The liver showing venous congestion (E). The pathological picture of the vaccinated group (C, F) was comparable to the non-infected control (A, D) (100x).

\section{REFERENCES}

1. Alexander D (2003). Newcastle disease, other avian paramyxoviruses, and pneumovirus infections. In YM Saif, HJ Barnes, JR Glisson, AM Fadly, LR McDougald \& D Swayne (Eds.), Diseases of Poultry (63-99). Ames: Iowa State University Press.

2. Alexander DJ (1997). Newcastle Disease and other avian Paramyxoviridae infections. In: Calnek, B. W. (ed.) Diseases of Poultry. Tenth edition. Iowa State University Press, Ames, USA. pp. 541-569.

3. Burnham MR, Peebles ED, Branton SL, Jones MS and Gerard PD (2003. Effects of F-strain Mycoplasma galisepticum inoculation at twelve weeks of age on the blood characteristics of commercial egg laying hens. Poult. Sci., 82: 397- 402.

4. Calderon de Anda F, Pollarolo G, Da Silva JS, Camoletto PG, Feiguin F, Dotti CG (2005). Centrosome localization determines neuronal polarity. Nature, 436(7051): 704-708.

5. Cheville NF, Stone H, Riley J and Ritchie EA (1972). Pathogenesis of virulent Newcastle disease in chickens. J. Am. Vet. Med. Assoc., 161:169-179.

6. Coles EH (1986). Veterinary Clinical Pathology. $4^{\text {th }}$ Edition, W.B. Saunders Company, Philadelphia, 17-19.

7. Darrell RK, Claudio LA, Patti JM (2013). Immune responses of poultry to Newcastle disease virus.
Developmental \& Comparative Immunology, 41(3): 447-453.

8. Doumas BT, Bayso DD, Carter RJ, Peter T, Schaffer R (1981). Determination of serum albumin. Clin. Chem., 27:1642.

9. Doumas BT, Biggs HG (1972). Determination of serum globulin. In: Cooper, editor. Vol. 7. Academic Press; New York: (Standard Methods of Clinical Chemistry)

10. Duncan DB (1995). Multiple Range and Multiple F-Test. Biometrics, 11: 142.

11. Dupont J, Tesscaurd S and Simon J (2009). Insulin signaling in chichen liver and muscle Gen. Comp. Endocrino., 163: 52-57.

12. El-Bahrawy A, Zaid A, Sunden Y, Sakurai M, Ito H, Ito $\mathrm{T}$ and Morita $\mathrm{T}$ (2016). Pathogenesis of renal lesions in chickens after experimental infection with $9 \mathrm{a} 5 \mathrm{~b}$ Newcastle disease virus mutant isolate. Vet. Pathol., 54(1):94-98.

13. Ezema WS, Okoye JOA and Nwanta JA (2009). LaSota Vaccination May Not Protect against the Lesions of Velogenic Newcastle Disease in Chicken. Tropical Animal Health and Production, 41:477-484.

14. Feldman BV, Zinkl JG (2000). Schalm's Veterinary Hematology, 5 th ed. Philadelphia, Lea Febiger pp. 1210-1218. 
15. Goryo M, Suwa T, Umemura T, Itakura C and Yamashiro $S$ (1989). Ultrastructure of bone marrow in chicks inoculated with chicken anaemia agent (MSB1-TK5803 strain). Avian Pathol., 18:329-343.

16. Harrison L, Brown C, Afonso C, Zhang J and Susta L (2011). Early Occurrence of Apoptosis in Lymphoid Tissues from Chickens Infected with Strains of Newcastle Disease Virus of Varying Virulence. Journal of Comparative Pathology, 145:327-335.

17. Hamid H, Campbell RSF, Parede L (1991). Studies of the pathology of velogenic Newcastle disease: Virus infection in non-immune and immune birds, Avian Pathology, 20(4):561-575.

18. Henry TJ (1974). Clinical Chemistry Principles and Techniques 2th ed. Harper and Row Publishers; New York.

19. Ismail HT (2017). Biochemical and hematological studies on the effect of Neem (Azadirachta indica) leaves aqueous extract on Newcastle disease vaccine and infection in broiler chickens. International Journal of Recent Scientific Research, 8(3): 15876-15884.

20. Jeon WJ, Lee EK, Lee YJ (2008). Protective efficacy of commercial inactivated Newcastle disease virus vaccines in chickens against a recent Korean epizootic strain. Journal of Veterinary Science, 9(3):295-300.

21. Koinarskin V, Angelov G and Lalev M (2001). Haematologic and blood electrolyte changes in broiler chickens experimentally invaded with Eimeria tenella. Bulgarian J. Vet. Med., 4:237-242.

22. Kouwenhoven B (1993). Newcastle disease. In: McFerran, J. B. and McNulty, M. S. (eds) Virus Infections of Birds. First edition. Elsevier Science Publishers, New York. pp. 341-361.

23. Kumar A, Jindal N, Shukla CL, Pal Y, Ledoux RD and Rottinghaus (2003). Effect of Ochratoxin A on Escherichia colichallenged broiler chicks. Avian. Dis., 47:415- 424.

24. Kral I and Suchy P (2000). Haematological studies in adolescent breeding cocks. Acta Vet. Brno, 69:189-194.

25. Lancaster EJ (1981). Newcastle disease - pathogenesis and diagnosis. World's Poultry Sci. J. 37, 26-33.

26. McDaniel LS and Chute HL (1961). Enzyme activity levels in chickens plasma. Am. J. Vet. Res., 22:99-103.

27. McFerran BJ and McCracken MR (1988). Newcastle disease. In: Alexander, J. D. (ed.) Newcastle Disease. First edition. Kluwer Academic Publishers, Massachusetts. pp. 161-183.

28. Najafi H, Ghalyanchi-Langeroudi A, Hashemzadeh M,Madadgar O, Karimi V, Khaltabadi-Farahani KR and Maghsoudlo H (2014). Comparison of laboratory parameters in the serum of SPF chickens infected with different iranian genotypes of infectious bronchitis virus. Iranian Journal of Virology 8(2,3): 1-6.

29. Nakamura K, Ohtsu N, Nakamura T, et al. (2008). Pathologic and immunohistochemical studies of
Newcastle Disease (ND) in broiler chickens vaccinated with ND: severe nonpurulent encephalitis and necrotizing pancreatitis. Veterinary Pathology, 45(6):928-933.

30. Ng WL, Chu CM, Wu AKL, Cheng VCC and Yuen KY (2005). Lymphopenia at Presentation Is Associated with Increased Risk of Infections in Patients with Systemic Lupus Erythematosus. Quarterly Journal of Medicine, 99:37-47.

31. Ojiezeh TI, Ophori EA (2015). Haemogram and Serum Enzymes Activities of Newcastle Disease Virus Challenged Broiler Chickens Following Supplemental Treatment with Aloe Vera Extract. J Clin Cell Immunol., 6: 282.

32. Ojok L and Brown C (1996). An immunohistochemical study of the pathogenesis of virulent viscerotropic Newcastle disease in chickens. J. Comp. Pathol., 115:221-227.

33. Parede L and Young PL (1990). The pathogenesis of velogenic Newcastle disease virus infection of chickens of different ages and different levels of immunity. Avian Dis., 34:803-808.

34. Reitman S, Frankel S (1957). Colorimetric method for determination of serum transaminases activities. Am. J. Clin. Path., 28:56-68.

35. Rivetz B, Bogin E, Hornstein $\mathrm{K}$ and Merdinger $\mathrm{M}$ (1975). Biochemical changes in chicken serum during infection with strains of Newcastle disease virus of differing virulence. I. Enzyme study. Avian Pathol., 4(3):189-197.

36. Rosenthal P (1997). Assessing liver function and hyperbilirubinemia in the newborn. National Academy of Clinical Biochemistry. Clin. Chem., 43:228-234.

37. Samour J (2006). Diagnostic value of hematology. In: Harrison GJ, Lightfoot TL eds. Clinical Avian Medicine. Palm Beach, FL: Spix; Publishing: 587-610.

38. Sanders GT, Pasman AJ, Hoek F (1980). Determination of uric acid with uricase and peroxidase. . Clin Chim Acta ., 101:299-303.

39. Schmidt EMS, Paulill AC, Caron LF, Filho TF, Augustini M, Ventura HLB and Locatelli-Dittrich R (2008). Evaluation of Experimental Vaccination against Newcastle Disease and the Blood Proteinogram in RingNecked Pheasants (Phasiannus coichicus) during Breeding Season. International Journal of Poultry Science, 7:661- 664 .

40. Talebi A (2006). Biochemical Parameters in Broiler Chickens Vaccinated Against ND, IB and IBD. International Journal of Poultry Science, 5(12):11511155.

41. Thijs K, Wobeser G, Leighton FA, Haines DM, Chelack B, Bogdan J, Hassard L, Heckert RA and Jose' Riva (1999). Newcastle disease in double crested cormorants from sakatchewan, with comparison of diagnostic methods. Journal of Wildlife Diseases, 35(1): 8-23. 
42. Trinder $P$ (1969). Determination of glucose in blood using glucose oxidase with alternative oxygen acceptor. Ann Clin Biochem., 6:24-27.

43. Velguth KE, Payton ME and Hoover JP (2010) Relationship of Hemoglobin Concentration to Packed Cell Volume in Avian Blood Samples. Journal of Avian Medicine and Surgery, 24:115-121.
44. Wang X, Zhou Q, Shen J, Yao J, Yang X (2015). Effect of difference doses of Newcastle disease vaccine immunization on growth performance, plasma variables and immune response of broilers. Journal of Animal Science and Biotechnology, 6(1):20.

45. Zijlstra NC (1960). Hematological assay methods, Clin. Chem. Acta., 5:719-721. 